G. Bernardini, Pisa (Chairman)

J. Tauc, Prague (Vice-Chairman)

G. H. Stafford, Chilton (Secretary)

H. Curian, Paris

M. Della Corte, Florence

S. F. Edwards, Manchester

L. Etienne-Amberg (Mrs), Geneva

L. Jansen, Geneva

J. M. Jauch, Geneva

A. Kastler, Paris

A. Schlater, Munich

E. W. D. Steel (Miss), CERN

L. Van Hove, CERN

The Conference Secretary is Mrs J. ffoulkes

\section{Arrangements in Florence}

The City of Florence has kindly placed at the disposal of the European Physical Society spacious facilities at two medieval palaces, the Palazzo Vecchio and the Or'San Michele, in the heart of the City. In spite of the medie$\mathrm{val}$ character of these palaces, they will be equipped with modern optical and acoustical facilities so that they will be technically suitable to cater for a meeting of approximately two thousand participants.

The two palaces are about $200 \mathrm{~m}$ from each other across a square. At the Palazzo Vecchio, four conference rooms are available - the "Salone dei 500 " (seating capacity up to 2000), the "Salone dei 200 " (capacity 600), the "Sala dei Gigli" (capacity 300 ) and the "Sala dell' Udienza" (capacity $200)$; the last room will be used for serving refreshments. At the Or'San Michele, two rooms with 400 seats each are available. Technical services including loudspeaker installations and recording equipment are being offered free of charge to the Conference by the Comitato Nazionale per I'Energia Nucleare.

Hotel bookings in Florence will be arranged directly by the Florence Office of the Italian Travel Agency, CIT. Since the Conference will take place just after Easter when the tourist season will already be under way, participants are strongly advised to reserve accommodation as soon as possible. The Main Secretariat of the EPS in Geneva will provide an accommodation questionnaire on request. This

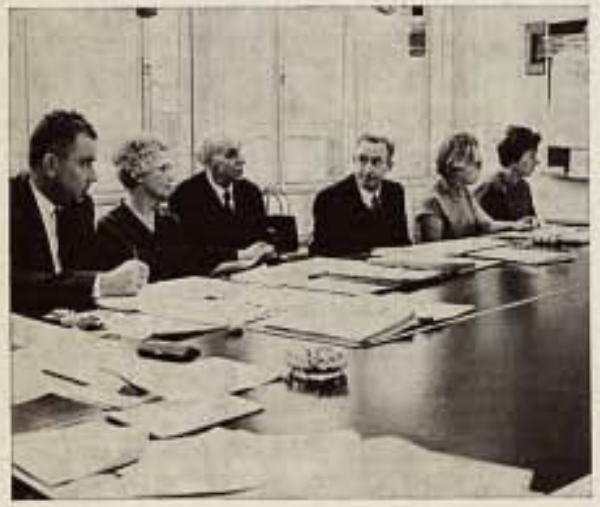

should be completed and sent directly to the CIT Florence Office.

To reduce the cost of attendance as much as possible, especially to help young physicists, special efforts are being made to secure low-cost accommodation and to organize cafeteriatype meals at minimum price. There are also two camping sites in the vicinity of the City. It is hoped that final details of such special arrangements will be available to intending participants before the end of January.

In order to economize as much as possible, the Main Organizing Committee has decided to dispense with all social activities, except for a concert by the Quartetto Italiano and a modest "Ladies Programme" comprising a visit to villas and gardens in Florence and its vicinity, and a fashion show at Pitti Palace organized by the famous fashion designer, Pucci.

\section{Registration}

The Conference is open to all physicists, regardless of whether they are members of the European Physical Society or not.

A registration fee of 30 Swiss francs is payable by every participant to cover part of the Conference budget. The major part of the budget is being generously offered to the European Physical Society by the Italian Government and by the City of Florence.

Further administrative details concerning the Conference are contained in a Conference Bulletin No. 1 obtainable together with an Attendance Application Form and an Accommodation Questionnaire from the Main Secretariat of the EPS (address on page 8).

The Main Organization Committee for the Florence Conference meeting on 11 December.

1. (Left to right) L. Jansen, Miss E.W.D. Steel A. Kastler, M. Della Corte. Mrs. J. ffoulkes, Mrs, L. Etienne.

2. (Left to right) G. Bernardini, G.H. Stafford, A. Schlüter, L. Van Hove, J. Tauc.

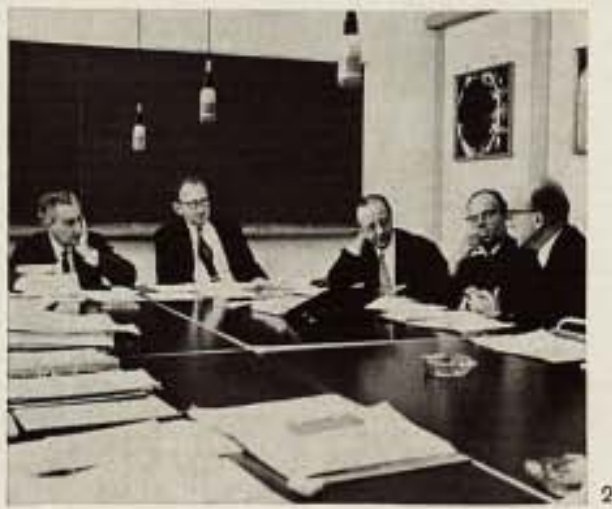

1969 Meetings

Notilfication of the following meetings to be held in April-August 1969 has been rocoived.

The meetings are listed - date; titie; venue; contact for information.

$31 \mathrm{MARCH}-3$ APRIL

National Atomic and Molecular Physics Congress

Manchester, UK

Meetings Officer, IPPS

47 Belgrave Sq, London SW 1

1-2 APRIL

Spring Meeting of British Radio Spoctroscopy Group: Applications of radio-frequency techniques to the study of electronic structure of solids Exeter, UK

Dr. J. E. Cousins, Physics Department,

The University, Exeter, Dovon, UK.

8-10 APRIL

Structure of Tracks of Charged Particles in Condensed Modia

Cambridge, UK

J. W. Boag, Dept, of Physics, Institute of Cancer Research, Clifton Avenue, Belmont Sutton, Surrey

9-11 APAIL

Physica and Engineering

London, UK

Meetings Officer, IPPS,

47 Belgrave Sq., Landon SW

9-11 APRIL

Structural Studies of Partially-Ordered Solids

University of Sussox, UK

Meotings Officer, IPPS,

47 Belgrave Sq. London SW 1

II APAIL

Meeting of DPG, Gorman Ceramic and German Glass Technological Societies :

Transport Processes in Anorganic NonMetallic Materials and their Structure

Mainz, Foderal Republic of Germany

W. Trior, D-6000 Frankfurt (Main).

Bockenheimer Landstr. 128

14-19 APRIL

International Conference on Fracture

Brighton, UK

R. W. Nichols, UKAEA, Reactor Matorials

Laboratory, Wigshaw Lane, Culcheth, Lancs.

15-18 APRIL

International Conference on Computer-Aided Design

University of Southampton, UK

Conforenco Socrotariat, IEE,

Savoy Place, London WC 2

15-18 APRIL

Physics of Liquids

Norwich, UK

Meetings Officer, IPPS,

47 Belgrave Sq.4 London SW

16-18 APAIL

Geoscienco Electronics Symposium

Washington, D.C., USA

M. E. Ringenbach, Director, Equipment Dovalopment Lab., U. S, Wonthar Bureat

RM, 201 Gramax Bldg.

8060 13th St., Silver Spring, Md. 20910

16-10 APAIL

International Magnetics Conference

Amsterdam, Netherlands

IEEE, Office of Technical Activities

Board, 345 East 47 th St., New York,

N. Y, 10017 


\section{2)-25 APRIL.}

Switching Techniques for Telecommuncation Networks

London, UK

Conference Department, IEE,

Savoy Place, London WC 2

\section{APRIL = 2 MAY}

Thin Films

Boston, Mass., USA

M. H. Francombe, Westinghouso Research Laboratories, Beulah Road,

Pittsburgh, $\mathrm{Pa} .15235$

\section{5-8 MAY}

International Microwavo Symposium

Dallas, Tex, USA

J. B. Horton, P.O. Box 5012, Texas Instr, Inc., Dallas, Tex. 75222

6-8 MAY

Nuclear Electronics Symposium

Ispra, Italy

Lueiano Stanchi, C.C.R. EURATOM, 21020 Inpra, Italy

7.9 MAY

International Conferance on Artificial Intelligence

Washington, D.C, USA

D. E. Walker, The Mitre Corporation Bedford, Mass 01730

\section{3-15 MAY}

1969 Spring Joint Computer Conference

Boston, Mass., USA

H.G. Asmus, AFIPS, 345 E 47th St., New York, N.Y, 10017

\section{0-23 MAY}

Symposium on Measuring Techniques for Low Magnetic Fields

Paris, Franco

Prof. Benoit, Faculté des Sciences de Paris, Paris

\section{6-28 MAY}

Laser Engineering

Washington, D.C., USA

F. R. Arams, Airborne Instruments

Laboratory, Melville, N.Y. 11746

\section{7-30 MAY}

Annual Meeting of the Sociáté de Chimie physique

Paris, France

Secrétaire général de la Sociéte de Chimie physique, 10 rue Vauquelin, 75 -Paris 50

\section{- JUNE}

International Conference on the Development of Science and Technology and thoir Impact on Society

Herceg-Novi, Yugoslavia

Organizing Committoe, Conference on Science and Sociaty, P.O. Box 353, Bolgrado

\section{Les Houches Summer School}

The 1969 Summer School of Theoretical Physics, an Institute of the University of Grenoble, will take place at Les Houches (Haute-Savoie) from 30 June to 23 August. It will be devoted to the study of physical problems regarding biological systems. The problems concerned are those where techniques of theoretical and experimental physics have been widely used for the benefit of biology (for example: biological macromolecules, membranes, sensory organs, muscles, nerves, application of nuclear magnetic resonance, electronic resonance, etc...). The purpose of the 1969 School is to familiarize physicists with the many biological problems to which physics can contribute in a novel manner.

Lecturers will be : J.-P. Changoux, M. Delbruck, G. Feher, P. G. de Gennes, M. Kasha, J.C. Kendrew, C. Kittel, A.M. Liquori, V. Luzzati, R.C. Shulman, J. Watson. Other lecturers have also been invited: M. Eigen, F. Gros, A.L. Hodgkin. The Director of Study will be Jean Matricon.

The number of registrations will be limited to 35 . The Selection Committee will choose physicists with a solid background in modern physics, coupled with some notion of biochemistry and a keen interest in the latest developments in biology. Additional information and Registration Forms are available on written request from :

Ecole d'été de Physique théorique,

76 Les Houches, Haute-Savoie, France

or

Cécile DeWitt,

Department of Physics, University of North Carolina,

Chapel Hill, North Carolina 27514, USA

Registration Forms should reach Les Houches duly completed, before 15 March.

\section{Summer Institute Uppsala-Beitoslølen}

An International Summer Institute in Quantum Chemistry, Solid-State Physics and Quantum Biology has been organized, by the Quantum Chemistry Group, Uppsala, in two parts : Part I, 27 July - 10 August at Uppsala, Sweden; Part II 11-31 August at Beitoslølen, Norway.

The course aims to take participants from "scratch" to current research level in a series of about 200 lecture hours. It is intended, essentially, for qualified students and research workers in theoretical physics and chemistry and in neighbouring experimental fields. Senior scientists are also welcome.

Lecturers will be : E. Brändas, J.-L. Calais (Assistant Director), O. Goscinski, F. Harris, P. Lindner, P.-O. Löwdin (Director), R. Pauncz.

Part I will consist of : introductory quantum mechanics, fundamental quantum mechanics, expansion methods in quantum mechanics, group theory and quantum mechanics and quantum theory of many-electron systems. Part II (based on Part I) consists of the following subjects : angular momenta, spin degeneracy problem, conjugated systems, time-dependent quantum theory, time-independent quantum theory, correlation problems in many-electron theory, Green-functions technique, advanced group theory, relativistic quantum mechanics, cohesive properties of solids, computational methods of quantum chemistry and quantum biology.

The all-inclusive fee is US $\$ 495$, covering the tutorial fee, accommodation and board. Preliminary applications should be sent as soon as possible to: The Director, Summer Institute, Quantum Chemistry Group, Box 518, 71520 Uppsala 1, Sweden. The application should contain name, postal address, affiliation, educational background, (examinations, degrees), field of studies or research, publications, age, citizenship, sex, information about accompanying dependents, and three passport photos of the applicant. For students a letter of recommendation is desired. 
9-13 JUNE

1st International Congtess on Colour

Stockholm, Sweden

Mr. Tonnquist, FOA 2, S104 50 Stockholm 80

\section{9-19 JUNE}

Colloquium on the Spectra of Meteorological Variables

Stockholm, Swoden

F. Eklund, Forsvarets Forskningsanstalt,

Avdelung 3, Research Institute of National

Defence, Stockholm 80

15-20 JUNE

International Data Processing Conference

Montreal, Canad

Mrs. M. Rafferty, Data Processing Management Association, 505 Busso Highway,

Park Bridge, III. 60068

\section{6-20 JUNE}

Classical and Relativistic Magnetohydrodynamics

Lille, France

Pham Mau Quan, Directeur de I'Institut de Mathématiques de la Faculté des Sciencos de Lille, Lille

\section{6-21 JUNE}

4th IFAC Congress

Warsaw, Poland

Honorary Secretary, UK Automation Council,

IEE, Savoy Place, London WC 2

\section{3-27 JUNE}

European Conference on Plasma Physics and Cantrolled Fusion

Utrecht, Netherlands

FOM-Instituut voor Plasma.Fysica,

Rijnhuizen, Postbus 7, Jutphass

30 JUNE - 1 JULY

Strength and Stability of Inorganic Fibres

University of Sussex, UK

Meetings Officer, IPPS,

47 Belgrave Sq., London SW 1

\section{JUNE -3. JULY}

Computer Science and Technology

Manchester, UK

Conference Department, IEE

Savoy Place, London WC 2

\section{7-11 JULY}

Structure and Properties of Solid Surfaces

Paris, Franco

J. Benard, Directeur de l'Ecole Nationale

Supórieure de Chimie de Paria, Paris

\section{7-11 JULY}

2nd European Symposium and Users' Summer School on Time of Flight Mass Spectromotry Salford, UK

J.E. Williams, Field Tech. Ltd.

Heathrow Aitport, Haunslow, Middlesex

8-10. JULY

International Conference on the Threo-Body Problem in Nuclear and Particle Physics Birmingham, UK

Administrative Officer, Department of Physics, P.O. Box 363 , University of Birmingham,

Birmingham 15

\section{4-19 JULY}

Atomic Absorptian Spectroscapy

Sheffield, UK

AAS Conference Secretary, Society for Analytical Chemistry, 9-10 Saville Row, London W 1

\section{JULY - 1 AUGUST}

Quantitative Relation batween Properties and Microstructure

Haifa, lsrael

Dr. A. Rosen, Dopartment of Materials Engineering, Technion City, Haifa

\section{Dubna}

From time to time, Europhysics News will carry information on the organization of National Physical Societios and on the international research centres in Europe. In this tirst issue we cover the Joint Institute for Nuclear Research at Dubna. The article is besed on intormation supplied by $M$. Lebedenko (Head of the Publishing Department, JINA).

Twelve years ago the name 'Dubna' began to occur in the scientific press. Dubna is a small town, situated $130 \mathrm{~km}$ north-west of Moscow on the river Volga. It first appeared on the map in 1956. From its beginnings, the reputation of this town has grown steadily, being the international scientific centre for the Socialist Republics, the home of the Joint Institute for Nuclear Research (JINR).

The story of the Institute began in Moscow in 1956 when representatives of the following governments met together: Albania, Bulgaria, China, Czechoslovakia, German Democratic Republic, Hungary, Korean Democratic Republic, Mongolia, Poland, Roumania and USSR. On 26 March an agreement was signed which came to be known as the Moscow Agreement for the establishment of the Joint Institute for Nuclear Research. At a later date, the Democratic Republic of Vietnam also joined, thus becoming the twelfth founder member of the Institute.

The Soviet Government handed over to the Organization two laboratories previously belonging to the Academy of Sciences : the Institute of Nuclear Problems and the Electro-Physical Laboratory. These two institutes were situated close to each other near the Volga, where it joins the Moscow canal close to the river Dubna. The existing installations (valued at half a million roubles) and highly qualified staff became the nucleus of the Joint Institute.

From the autumn of 1956, scientists from the Member States began to arrive at Dubna. At that time, the Member States did not possess adequate facilities of their own for largescale work particularly in high-energy physics which was to be one of the main activities of the Institute.

After a short time the two existing laboratories were joined by a third the Laboratory of Theoretical Physics. Other laboratories followed, each the equivalent of a modern large-scale institute. There are now six laboratories which, in their over-all scope, cover all the principal lines of modern nuclear physics. The work of the research

\section{Lebedenko}

scientists of Dubna has become internationally known. Preprints prepared at Dubna are distributed, on an exchange basis, to scientists in 42 countries in all 5 continents, and there is no country where the field of nuclear physics is developed that has not seen its senior scientists visiting Dubna, and scientists from Dubna visiting its own centres of research.

The essential aims of the centre are clearly set out in the Moscow Agreement and again in the Constitution of the Institute:

1. To foster collaboration in nuclear research by scientists in the Member States

2. To promote nuclear physics research in the Member States by the exchange of information and results of both theoretical and experimental research

3. To maintain close relations with other national and international scientific research organizations engaged on the development of physics and on the global applications of atomic energy

4. To promote the most effective use of the intellectual effort available in the Member States.

Over the years there have been many changes. The Member States have now their own institutes, laboratories and scientific groups, and schools of scientific workers in the field of nuclear physics. These groups are often led by people who have at some time worked at Dubna or who have worked in close collaboration with the Joint Institute. Generally speaking the equipment that is to be found at Dubna is larger and more highly developed than exists in Member States, but the Member States do now have well-equipped laboratories of their own which makes real collaboration with Dubna possible.

\section{ORGANIZATION}

The essential principles involved in the management of the centre were set down in the Convention. Finance is provided by the Member States (according to their financial means), contributions ranging from $0.05 \%$ to near 